\title{
Confirmation of crayfish plague in Italy: detection of Aphanomyces astaci in white clawed crayfish
}

\author{
Cesare Cammà*, Nicola Ferri, Daniela Zezza, Maurilia Marcacci, \\ Alessandra Paolini, Luciano Ricchiuti, Rossella Lelli
}

Istituto Zooprofilattico Sperimentale dell'Abruzzo e del Molise ‘G. Caporale', Via Campo Boario Teramo, Italy

\begin{abstract}
In the summer of 2009, high levels of mortality among white clawed crayfish Austropotamobius pallipes were observed in 3 watercourses of central Italy. PCR and culture methods were used to detect the causative agent of the disease. Two strains of Aphanomyces spp. were isolated and identified by PCR and DNA sequencing as Aphanomyces astaci and A. repetans. This is the first crayfish plague outbreak in Italy to be confirmed by the isolation in culture of a pathogen from Austropotamobius pallipes.
\end{abstract}

KEY WORDS: Crayfish plague $\cdot$ Aphanomyces astaci $\cdot$ Aphanomyces repetans $\cdot$ Austropotamobius pallipes $\cdot \mathrm{PCR} \cdot$ Culture method

\section{INTRODUCTION}

Crayfish plague is an infectious disease caused by Aphanomyces astaci that affects freshwater crayfish. In susceptible species, the infection can cause the extinction of entire populations. The pathogenic agent is a fungus-like microorganism belonging to the class Oomycota which includes among others pathogens of crustaceans, fish and plants (Diéguez-Uribeondo et al. 2009). All European crayfish species are highly susceptible to crayfish plague: the noble crayfish Astacus astacus, the Turkish crayfish Astacus leptodactylus, the stone crayfish Austropotamobius torrentium and the white clawed crayfish Austropotamobius pallipes, which is the most commonly found native crayfish species in Italy (Gherardi 1999, Trontelj et al. 2005). North American crayfish species such as Pacifastacus leniusculus, Procambarus clarkii and Orconectes spp. as well as fish can act as carriers of the pathogen (Hall \& Unestam 1980, Dieguez-Uribeondo \& Söderhäll 1993).

The first crayfish mortalities in Europe were reported in northern Italy in 1859 (Cornalia 1860, cited in Alderman 1996). Subsequently, the crayfish plague spread to Germany, France, and to eastern and northern European countries (Alderman 1996).

In Italy from 1900 to 2009 several crayfish population mortalities were reported but there was no confirmation of cause (Gherardi 1999). A strain isolated from Procambarus clarkii in the province of Bologna (Italy) showed morphological characteristics suggesting Aphanomyces astaci (Galuppi et al. 2001). However, the isolate was further genetically characterised as $A$. repetans which failed to kill crayfish under standard experimental infection conditions (Royo et al. 2004).

High levels of mortality were observed during the summer of 2009 in 3 populations of Austropotamobius pallipes living in various watercourses of the Molise region in central Italy.

\section{MATERIALS AND METHODS}

Crayfish samples and histopathology. The first episode of crayfish mortality in the Trigno river (Carovilli, Molise) was reported on 15 August 2009 (Fig. 1). Five specimens of Austropotamobius pallipes 


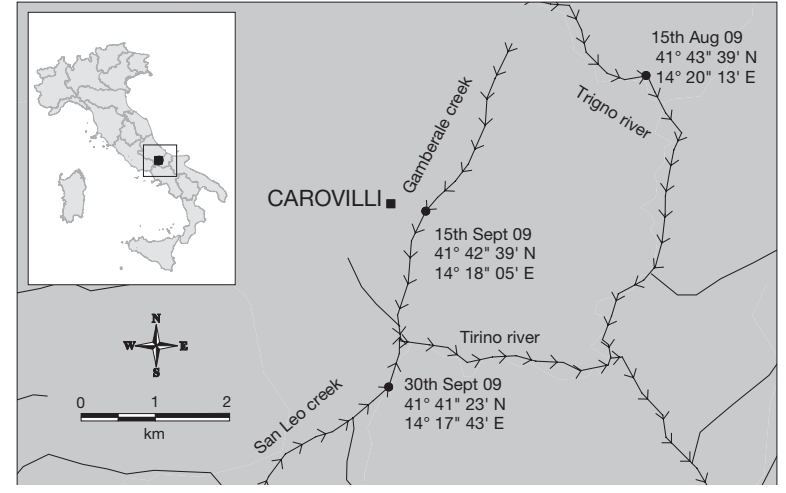

Fig. 1. Austropotamobius pallipes. Crayfish mortality sites in Molise region, Italy

delivered to the laboratory were analysed by histopathological examination as follows: crayfish were fixed by injecting $10 \%$ neutral-buffered formalin into the cephalotorax and abdomen. The crayfish were then dissected and tissues placed in a decalcifier solution (Bio-Optica) for $8 \mathrm{~h}$, rinsed in distilled water, stored in $70 \%$ ethanol and processed by paraffin embedding and staining with haematoxylin and eosin, periodic acid-Shiff (PAS) and Giemsa.

Agent isolation and microscopic method. One month later, 5 recently dead crayfish were collected from the Gamberale creek, a branch of the Trigno river. Isolation of the pathogen was attempted from soft abdominal cuticle using the isolation medium (IM) previously described for the isolation and culture of Aphanomyces astaci (Alderman \& Polglase 1986).

On 30 September, 2 healthy and 1 dead crayfish were collected from another branch of the Trigno river, the San Leo creek; 2 wk later, 16 dead crayfish and 1 moribund crayfish were collected from the same site. The crayfish that was still alive showed the typical signs of crayfish plague such as loss of co-ordinated movements and the absence of the tail flip escape reflex. All the collected specimens were identified as male Austropotamobius pallipes.

Wet mounts prepared from portions of the exoskeletons were examined under a light microscope. Part of the soft abdominal and one pereiopod joint cuticle of the moribund crayfish were used to isolate the pathogen in IM agar.

PCR-based diagnoses. Total DNA extraction from soft abdominal cuticle specimens of 17 crayfish (16 dead and 1 moribund Austropotamobius pallipes) and from small pieces of IM agar containing suspected colonies were carried out using Maxwell DNA tissue kit (Promega) according to the manufacturer's instructions.

DNA from cuticle samples was tested by means of Primers 42 and 640 designed for a single round PCR specific for Aphanomyces astaci (Oidtmann et al.
2006). A PCR using universal primers ITS1/ITS4 described by White et al. (1990) for amplification of about $750 \mathrm{bp}$ of rDNA including Internal Transcribed Spacers (ITS) 1 and 2 was performed when the samples produced negative results with the specific PCR. Both PCRs were carried out in a $50 \mu$ reaction volume containing $1 \times$ GeneAmp $^{\circledR}$ PCR Gold Buffer, $2 \mathrm{mM} \mathrm{MgCl}$, 0.2 mM dNTPs, 3 Units of AmpliTaq Gold ${ }^{\circledR}$ DNA Polymerase, $2 \mu \mathrm{M}$ of each primer and $5 \mu \mathrm{l}$ of extracted DNA.

The amplification was performed in a GeneAmp ${ }^{\circledR}$ PCR System 9700 (Applied Biosystems) with the following thermal profile: $10 \mathrm{~min}$ of initial denaturation at $95^{\circ} \mathrm{C}, 45$ cycles of $95^{\circ} \mathrm{C}$ for $30 \mathrm{~s}$, annealing step at $59^{\circ} \mathrm{C}$ $\left(54^{\circ} \mathrm{C}\right.$ using ITS1/ITS4) for $30 \mathrm{~s}, 72^{\circ} \mathrm{C}$ for $45 \mathrm{~s}$ followed by a final extension of $5 \mathrm{~min}$ at $72^{\circ} \mathrm{C}$.

PCR products obtained with both methods were purified using the QIAquick PCR Purification Kit (Qiagen) and sequenced by BigDye Terminator v.3.1 (Applied Biosystems) and 3130 XL Genetic Analyzer (Applied Biosystems). Raw sequence data were assembled using Contig Express (Vector NTI suite 9.1; Invitrogen) and consensus sequences were submitted to a Blast search (http://blast.ncbi.nlm.nih.gov/Blast.cgi).

\section{RESULTS}

Histological examinations showed infiltration of hyphae in the exoskeleton, mainly in the joints of antennae and pereiopods, and in the soft cuticle of the abdomen (Fig. 2). Infiltration affected the underlying tissue, epidermis, hypodermis and skeletal muscle

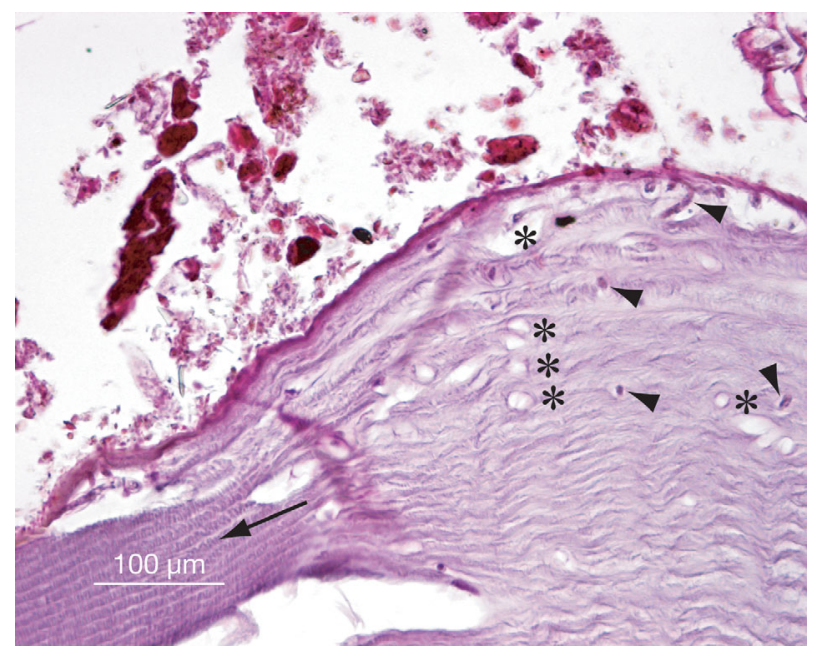

Fig. 2. Austropotamobius pallipes. Histogical examination. Severe hyphal infiltration in the soft abdominal cuticle of a dead crayfish. Arrow: undamaged exoskeletal area; asterisks: paths carved out by hyphae; arrowheads: hyphae within paths. Periodic acid-Schiff stain 


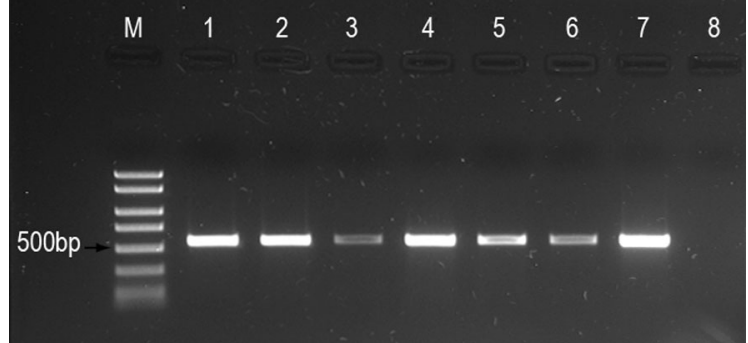

Fig. 3. Austropotamobius pallipes. PCR testing for Aphanomyces astaci using Primers 42 and 640 (Oidtmann et al. 2006). Amplicons obtained were of the expected size of $569 \mathrm{bp}$. Lane M: PCR Marker (Sigma); Lanes 1 to 6: DNA extracted from soft abdominal cuticles of 6 dead crayfish; Lane 7: DNA extracted from soft abdominal cuticle of 1 moribund crayfish; Lane 8: PCR negative control

with inflammation and necrosis. In some areas hyphae were encapsulated by melanin. Histological examinations did not reveal viral intranuclear inclusions: instead bacteria were observed near hyphal infiltration, without septicemic spread features.

The presence of aseptate hyphae $9 \mu \mathrm{m}$ in width with spots of melanisation in different areas of soft cuticle was observed in the wet mounts. These findings provided circumstantial evidence of crayfish plague.

Cuticle samples from 16 dead and from the moribund crayfish tested positive by specific PCR for Aphanomyces astaci (Fig. 3).

Two colonies that morphologically resembled Aphanomyces sp. were grown after $5 \mathrm{~d}$ of incubation in IM agar, and were subcultured in fresh agar medium to avoid overgrowing of bacteria and fungi (Oidtmann et al. 1999). One isolate was found to be positive for the specific PCR and the sequence (GenBank Accession Number GU174502), submitted to a Blast search, scored $100 \%$ identity to the published sequences of $A$. astaci while the other colony gave negative results for the specific PCR. However, a PCR product was obtained using ITS1/ITS4 primers and the sequence of the amplicon (GenBank Accession Number GU182321) showed $99 \%$ identity with a strain of A. repetans isolated in Italy from Procambarus clarkii (GenBank Accession Number AY683892) (Royo et al. 2004).

\section{DISCUSSION}

Crayfish plague is considered to be the principal cause of mass mortalities in native crayfish populations in Europe (Holdich 1999). The present study describes the first documented outbreak of crayfish plague in Italy. The clinical diagnosis was supported by a series of laboratory findings which included PCR and DNA sequencing recently proposed as the recommended methods for presumptive and confirmatory diagnosis respectively (OIE 2009).

The origin of the outbreak is unknown although epidemiological investigations are ongoing. The introduction of American crayfish species carrying Aphanomyces astaci is generally considered to be the main risk factor for the spread of the infection (DiéguezUribeondo \& Söderhäll 1993). However, North American crayfish have not been found to date in the watercourses where the disease was identified.

Two morphologically indistinguishable strains of Aphanomyces were isolated and identified by molecular methods as A. astaci and A. repetans. The latter was described as a saprotrophic species able to produce repeated zoospore generations, but it does not express chitinase constitutively and it fails to kill crayfish in virulence assays (Royo et al. 2004).

This finding confirms the importance of specific molecular diagnostic methods for Aphanomyces astaci. Isolation in culture is time-consuming and often fails, because of the slow growth rate compared to other Oomycetes and fungi that can colonise crayfish cuticle, or because of the presence of bacteria that inhibit $A$. astaci growth (Oidtmann et al. 1999, 2004). PCR was crucial in identifying a suspected $A$. astaci isolate without the use of reinfection of susceptible crayfish, as previously suggested (Royo et al. 2004). PCR should also be very useful in monitoring the presence of Aphanomyces astaci in Italy, particularly in the invasive North American crayfish populations. Further molecular tools such as RAPD-PCR and epidemiological studies are needed to genetically characterise the isolates and to investigate the origin of the Italian crayfish plague outbreak (Huang et al. 1994).

To our knowledge this study represents the first time that Aphanomyces repetans has been isolated from Austropotamobius pallipes. Moreover, there is increasing concern among crayfish researchers and diagnosticians about other possible causes of epizootics in native European crayfish (Edgerton et al. 2004). Therefore viruses, rickettsia-like organisms and microsporidia should also be considered in future crayfish mortality.

Acknowledgements. We are grateful to Prof. F. Quaglio, Faculty of Veterinary Medicine, University of Padua, for his guidance and technical support in histological examinations. Thanks to L. Petrucci for helping in culture method. We are indebted to F. Monaco and P. Calistri for critical comments on the manuscript.

\section{LITERATURE CITED}

Alderman DJ (1996) Geographical spread of bacterial and fungal diseases of crustaceans. Rev Sci Tech Off Int Epizoot 15:603-632

Alderman DJ, Polglase JL (1986) Aphanomyces astaci: isola- 
tion and culture. J Fish Dis 9:367-379

Cornalia E (1860) Sulla malattia dei gamberi. Atti Soc Ital Sci Nat II:334-336

Diéguez-Uribeondo J, Söderhäll K (1993) Procambarus clarkii Girard as a vector for the crayfish plague fungus, Aphanomyces astaci Schikora. Aquac Res 24:761-765

Diéguez-Uribeondo J, García MA, Cerenius L, Kozubíková E and others (2009) Phylogenetic relationship among plant and animal parasites, and saprotrophs in Aphanomyces (Oomycetes). Fungal Genet Biol 46:365-376

Edgerton BF, Henttonen P, Jussila J, Mannonen A and others (2004) Understanding the causes of disease in European freshwater crayfish. Conserv Biol 18:1466-1474

Galuppi R, Quaglio F, Maxia M, Morolli C, Tampieri MP (2001) Fungal infections in allochthonous freshwater crayfish in Northern Italy. Freshw Crayfish 13:267-273

Gherardi F (1999) The situation in Italy. In: Gherardi F, Baldaccini GN, Ercolini P, Barbaresi S and others (eds) Crayfish in Europe as alien species. AA Balkema, Rotterdam, p 107-128

Hall L, Unestam T (1980) The effect of fungicides on survival of the crayfish plague fungus, Aphanomyces astaci, oomycetes, growing on fish scales. Mycopathologia 72: 131-134

Holdich DM (1999) The negative effects of established crayfish introductions. In: Gheradri F, Baldaccini GN, Ercolini $\mathrm{P}$, Barbaresi $\mathrm{S}$ and others (eds) Crayfish in Europe as alien species. AA Balkema, Rotterdam, p 31-48

Huang TS, Cerenius L, Söderhäll K (1994) Analysis of genetic diversity in the crayfish plague fungus, Aphanomyces astaci, by random amplification of polymorphic DNA.

Editorial responsibility: Grant Stentiford,

Weymouth, UK
Aquaculture 126:1-9

Oidtmann B, Schmid I, Rogers D, Hoffmann RW (1999) An improved isolation method for the cultivation of the crayfish plague fungus, Aphanomyces astaci. Freshw Crayfish 12:303-312

> Oidtmann B, Schaefers N, Cerenius L, Söderhäll K, Hoffmann RW (2004) Detection of genomic DNA of the crayfish plague fungus Aphanomyces astaci (Oomycete) in clinical samples by PCR. Vet Microbiol 100:269-282

- Oidtmann B, Geiger S, Steinbauer P, Culas A, Hoffmann RW (2006) Detection of Aphanomyces astaci in North American crayfish by polymerase chain reaction. Dis Aquat Org 72:53-64

OIE (World Animal Health Organisation) (2009) Manual of diagnostic tests for aquatic animals. Chapter 2.2.1. Crayfish plague (Aphanomyces astaci). Office International des Epizooties, Paris, p 63-77

> Royo F, Andersson G, Bangyeekhun E, Muzquiz JL, Söderhäll K, Cerenius L (2004) Physiological and genetic characterisation of some new Aphanomyces strains isolated from freshwater crayfish. Vet Microbiol 104:103-112

Trontelj P, Machino Y, Sket B (2005) Phylogenetic and phylogeographic relationships in the crayfish genus Austropotamobius inferred from mitochondrial COI gene sequences. Mol Phylogenet Evol 34:212-226

White TJ, Bruns T, Lee S, Taylor J (1990) Amplification and direct sequencing of fungal ribosomal RNA genes for phylogenetics. In: Innis MA, Gelfand DH, Sninsky JJ, White TJ (eds) PCR protocols: a guide to methods and applications. Academic Press, San Diego, CA, p 315-322

Submitted: November 11, 2009; Accepted: January 25, 2010 Proofs received from author(s): April 1, 2010 